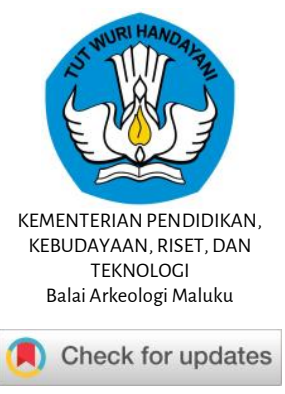

Kapata Arkeologi, 17(1) 2021, 33-42

p-ISSN: 1858-4101, e-ISSN: 2503-0876

KAPATA ARKEOLOGI

SCIENTIFIC JOURNAL OF ARCHAEOLOGY AND CULTURAL STUDIES

Accredited by the Indonesian Ministry of Research, Technology, and Higher Education (RISTEKBRIN)
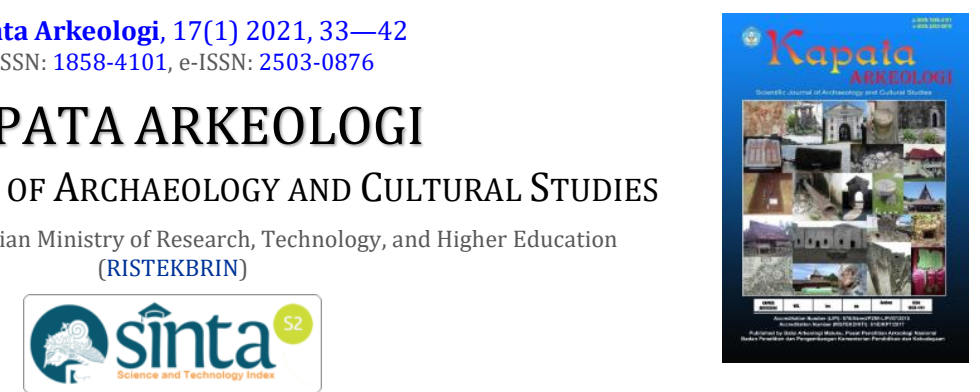

http://kapata-arkeologi.kemdikbud.go.id/

\title{
A STUDY OF THE TOPONYMS OF NATURAL TOPOGRAPHY IN SiaK, Riau Province
}

\author{
Imelda Yance \\ Balai Bahasa Riau \\ Jl. HR. Soebrantas Panam No. Km. 12,5, Simpang Baru, Pekanbaru, Riau 28292, Indonesia \\ iyance69@gmail.com \\ Received: 28/02/2018; revisions: 17/08 — 28/10/2019; accepted: 06/01/2021
}

\begin{abstract}
The toponyms of the landscape in Siak Regency as a former center of the Malay Kingdom in Riau is very significant in illustrating the landscape of its environment. The significance of toponym can be seen in its relation to humans, history, geography, and even culture. This research focuses on the natural topographical toponyms, including hills, lakes, straits, capes, and rivers in Siak Regency, Riau Province with anthropological linguistic reviews. This research was conducted with a qualitative approach and descriptive method. From the data analysis, the natural toponyms in Siak Regency are named after Riau Malay language. The lexicon is a compound word or phrase that always starts with a generic name. In general, physical aspects have underlain the toponyms. There are not many toponyms underlain by social, cultural, or physical-social aspects. The toponyms serve to mark, become an identity (formal), describe, and as a reminder of the historical or socio-cultural background of a landscape. The meaning of the lexicon reveals the closeness of the relationship between Siak Malay community and its environment. The natural toponyms in Siak Regency reflect the cognition of Siak Malays related to their environment, both physical, social, and cultural environments, in terms of utilizing and connecting processes, assimilation concept, accommodation concept, empirical concept, and creativity.
\end{abstract}

Keywords: toponym; Siak Regency; Siak Malays; anthropological linguistics; Riau

\section{INTRODUCTION}

Terminologically, the term toponym is formed from the word topos 'place/'surface' and nym 'name.' In English, there are two terms related to that name, namely toponyms and toponymy. Toponyms mean 'place-names' while toponymy refers to its science. Toponyms are also known as geographical names or place names (Kleinedler, 2014). In the Fifth Edition of Kamus Besar Bahasa Indonesia of 2016, there is the term toponymy, which refers to two understandings: (1) 'place-names' and (2) 'onomastic branch which investigates placenames.' In the first sense, Bahasa Indonesia has found other terms, namely nama unsur geografis (geographical element names), nama geografis (geographical names), nama (topography), or nama unsur rupabumi (topographical element names). In Perpres (2006) (Presidential Regulation) Number 112 and Permendagri (2008) (Minister of Home Affairs Regulation) Number 39 , toponymy in the sense of place names is called nama rupabumi (topographical names). In this research, the term toponyms used refers to the meaning of 'placenames.' Theoretically, Kadman views toponym as " $a$ proper noun applied to a topographic feature." Helleland (2012) sees it as "an oral or written linguistic expression that two or more persons use with reference to a particular spatial perception" (Cekula, 2016: 131). Toponyms are given by humans with the primary objective to identify or recognize their physical environment, namely either natural or artificial topographies. Communication needs to underlie the action since humans need a name for the appointed geographical object when communicating (Rais et al., 2008). Such topographical element naming is referential. Such a toponym is not understood better as a language unit to identify a geographical area. When a toponym is mentioned, someone will immediately point to a specific geographical area, though the toponym is not only referential.

In its development, the toponym turns out to contain various aspects such as historical, social, political, and cultural aspects. Various toponym studies have shown this fact. Qian et al. (2016) summarize various sources of wealth contained in a toponym. The toponym represents the subjective interpretation of the residents on their 
environment. A toponym extracts spatial, temporal, and landscape information. Toponym also stores information about specific topographies and ethnicities. Also, the toponym stores information about human migration, religious and cultural traditions, and local languages. Thornton (1997) views toponym as a cultural artifact that contains the cultural information about the community that creates it. The wealth of information contained in it makes toponym a moving object of study. Various branches of science study it with their perspectives, ranging from linguistics, history, anthropology, sociology, to psychology. Assadorian (2017) collects 12.000 Iranian toponyms in the Azerbaijan area. The data are categorized into various aspects: the origin, meaning, and procedure of the toponym formation. Assadorian (2017) succeeds in proving that the original Iranian elements are present in the toponyms in the area, including in the Turkish-speaking area. Through the research, the researcher strengthens the identity of Iranians in the Azerbaijan area, including in the Turkishspeaking area of Iran.

Madden (2018) discusses renaming conflicts due to the presence of the elite housing complexes in an area using archival and ethnographical data from an area in Brooklyn, New York. Madden (2018) finds that the real estate developers and residents of the elite housing use the toponyms to legitimize their privileged position. Meanwhile, the residents around the housing experience the symbolic changes due to the toponym changes. The conflict surrounding the environment renaming is seen as a symbol for fighting over the resources, property, identity, and ownership in urban space. Cekula (2016) associates toponym with identity in the northern and southern regions of Latvia. In the findings, vegetation names dominating the toponym. The vegetation is in the form of trees and grasses. Besides, there are also places named after their topographical features. Those names are the identities of the two regions.

Jordan (2014: 210) finds the primary function of toponym in relating human beings to their territory, namely (1) "place names often reflect the characteristics of geographical features important for a certain community"; (2) "place names mark the territory of a community;" (3) "place names structure territory mentally;" (4) "place names support emotional ties between people and place and promote in this way space-related identity building." Klugah (2013) connects the toponym with history. The object of Klugah's (2013) research was the toponyms contained in the narrative texts of Asogli's migration in Ghana. Through the toponyms, he extracted scientific, historical information about the Asogli migration route. Klugah (2013) used Tent \& Blair's (2011) toponym theory and qualitative method in carrying out his research. Klugah (2013) found that toponym acts as a historical preservative tool.
Toponyms were used to mark certain events on the migration route. In terms of linguistic, he also found that the toponyms of Asogli's migration narratives have brought various grammatical structures together through the agglutination process. Helleland (2012) shows in his publication that toponym is more than a referential function. Toponym can be a memory link to the past. Helleland (2012) reveals that some toponyms in Norway can reflect or induce personal feelings and collective identities attached to certain places. Toponym can also be utilized to develop the identity of a territorial area.

From the various studies above, it can be seen that toponym is indeed a vibrant field of study. However, in Indonesia, similar studies have not developed. Experts in the field of geography in Indonesia have mostly researched toponym. There are not many studies by experts in other fields, such as language, culture, and history. Ruspandi \& Mulyadi (2014), for example, examined the toponyms of the Cirebon area. They analyzed the aspects that underlie the artificial topography naming and people's perceptions of the naming. The two researchers conclude that the toponyms in the area are underlain by physical, social, and cultural aspects. In terms of perceptions, it turned out that only $31.52 \%$ of respondents know the meaning and origin of the toponyms in the area. Meanwhile, Mutakin (1999: 26) concludes that there are two considerations taken by the place name givers, namely (1) experiences related to the natural and artificial processes; and (2) human ideas, hopes, ideals, and tastes towards a place or characteristics that have been given by the nature itself. The specific or dominant phenomena will be used as the toponym.

The lack of interest in toponym research in Indonesia is regrettable. The toponym is like the window of a house. The toponym window can obtain lots of information. Taking into account the background and uniqueness of natural topographical toponyms in Siak Regency, Riau Province, which show significant symptoms, the researcher focuses on the research on natural topographical toponyms, namely on hill, lake, strait, lake and river toponyms. Apart from the fact that there is no toponym research in the area, the history of Siak Regency as a former Malay sultanate in Indonesia is also considered. This toponym research is related to the cognition system of the supporters/stakeholders of the culture (Siak Malay tribe). This research was conducted with an anthropological linguistic perspective, which relates between the linguistic elements and cultural elements, especially culture as a cognition system (one of the three forms of culture, including systems of cognition, idea, knowledge, thought, behavior system, and artifacts). Foley (1997) argues that the role of anthropological linguistics is to reveal hidden meanings in the form of various languages or registers and styles, 
including toponym. Systems of cognition, idea, thought, knowledge possessed by supporting groups of culture are part of the hidden meanings meant by Foley (1997).

The toponym is represented in the form of language, according to Hameed (2015), which has three core aspects: (1) form, (2) meaning, and (3) function. In Kramsch \& Widdowson's (1998) view, the form of language is a system that reflects, embodies, and symbolizes the cultural reality of the native speakers. The form is represented in words. Through these words, the cultural reality is revealed. The power of language, especially words, in relation to the way of thinking of a group is also agreed upon by Wierzbicka $(1997: 1,5) \ldots$. that words with special, culture-specific meanings reflect and pass on not only ways of living characteristic of a given society but also ways of thinking."

The connection between language and thought is first put forward by Johann Herder and Wilhelm von Humbolt; it is called the relativity of language. They say that "different people speak differently because they think differently, and that they think differently because their language offers them different ways of expressing the world around them." This idea was then used by Franz Boas, Edward Sapir, and then Benjamin Lee Whorf, who is very famous for the Sapir-Whorf hypothesis (Kramsch \& Widdowson, 1998: 11).

There is one branch of anthropology, namely cognitive anthropology, that specializes in the expression of supporting the cognition system of a culture. Experts in that field believe that the most important form of culture is the system of cognition/idea/thought/knowledge. Its urgency exceeds the form of other cultures, beyond objects (artifacts) or behavioral systems. Related to that, Tyler (1969) views that each person has a distinctiveness or uniqueness in sensing and organizing various material phenomena (objects, events, behaviors, and emotions). The uniqueness of distinctiveness can be found in its original form, namely in language. Language becomes a symbol of concepts that are inferred through sensing and organizing. The toponym is in the form of language, which is the result of actions by a group of people in sensing and organizing material phenomena they encounter. The form of language is a recording of a concept born from the encounter of its creators with material phenomena. Based on language (linguistics), various cognitions or life views of the toponym creators can be revealed. This view is the essence of work carried out based on the anthropological linguistic approach.

More specifically, toponym linkage in the constellation between language, cognition, and the environment is an essential aspect of cultural analysis. Topographical names in the form of language communicate many things to us. The scope is not only in the structure and content of the physical environment itself but also in the way humans receive, conceptualize, classify, and utilize the environment. Accordingly, toponym provides valuable insights into the way humans experience the world and describe landscapes to interpret and communicate their experiences. That is the reality of linkage between language, cognition, and the environment in the topographical names (Thornton, 1997).

The views above become the guideline in this research, which examines the toponyms in one of the regencies in Riau Province, namely Siak Regency. The name of this regency is very close to the name of one of the topographical names, which is very famous in Indonesia (Siak River). Moreover, this regency is considered a landmark of the last Malay sultanate heritage in Sumatera, namely Siak Sri Inderapura Sultanate. Toponyms in Siak Regency, Riau Province, are assumed to have similar qualities with other topographical names in various parts of the world because of the concept of cultural universality. Furthermore, topographical names in Siak Regency are also assumed to have unique characteristics that indicate the concept of cultural relativity.

The description of language levels until the cognition disclosure of a cultural group in element study of an intangible culture is an attempt to understand the system of idea/thought/knowledge of that cultural group. The effort can lead to understanding, which may result in mutual respect for the culture of a group. That is the main benefit of social science and humanity research, including this research. Natural toponym in Siak Regency is a record of place names list that can be a valuable input for the Language Agency to enrich the Indonesian Dictionary (Tim Redaksi KBBI, 2018), for example. Methodologically, similar research can be carried out on other topographies in Siak Regency and other regencies in Riau Province, even on other toponyms in all Indonesian areas.

Indonesian topographical details are numerous. The Decree of Minister of Home Affairs Regulation (2008) Number 39 categorizes topography into two, natural topography and artificial topography. The naming is based on the way it is formed. The natural topography is formed naturally. This group includes islands, archipelagoes, mountains, highlands, hills, plateaus, caves, valleys, capes, peninsulas, oceans, seas, undersea mountains, troughs, straits, bays, lakes, rivers, and estuaries. Meanwhile, artificial topography is made by humans. It includes airports, dams, reservoirs, bridges, tunnels, lighthouses, settlements, industries, land/sea management areas, temples, monuments, administrative areas (Rais et al., 2008). This research is limited to natural topographical toponyms.

Foley's (1997) view of the cultural (anthropological) meaning behind the language (linguistics), in this case, 
is the natural topographical toponyms in Siak Regency, is referred to as the main guideline for the research. From a language standpoint, Hameed's (2015) notion about topography, which consists of form, meaning, and function, is used as a benchmark. Cekula's (2016) and Jordan's (2014) research on the relationship between toponym and geographical, identity, and mental aspects are also used as references to see the relationship between toponym and environment. Next, Kramsch \& Widdowson's (1998), Wierzbicka's (1997), and Thornton's (1997) views guide linking toponym and cognition system. These views are used to analyze the natural topographical toponyms in Siak Regency, which include (1) general description of Siak Regency, (2) toponyms and geographical, social, and cultural aspects (3) toponyms functions, and (4) cognition system of Siak Malays reflected in natural topographical toponyms.

The aim of this research is to describe and reveal (1) general description of Siak Regency, (2) toponyms and geographical, social, and cultural aspects of Siak Regency (3) toponyms functions in Siak Regency, and (4) cognition system of Siak Malays reflected in the toponyms of Siak Regency.

\section{METHODS}

In toponym research, there are three main approaches used: qualitative, quantitative, and a combination of qualitative and qualitative approaches. The most widely used approach is qualitative (Tent, 2015). Following the problem and aim of the research, the approach used in toponyms research in Siak Regency was qualitative. According to Moleong (2014: 9).

"Qualitative research is research that intends to understand the phenomenon of what is experienced by the research subject such as behavior, perception, motivation, action, etc. in a holistic manner and by describing in the form of words and language, in a special natural context and by utilizing various natural methods."

The choice of approach was also based on one of the qualitative research criteria presented by Sugiyono (2013) to understand the meaning of the visible data. Meanwhile, the method used was descriptive, namely “... a method in examining the status of a group of humans, an object, a set of conditions, a system of thought, or a class of events nowadays" (Nazir, 2003: 4).

This research used the perspective of anthropological linguistics, an interdisciplinary field, a combination of linguistics and anthropology. Anthropological linguistics is different from linguistic anthropology. Anthropological linguistics belongs to linguistics, while linguistic anthropology belongs to anthropology. The meaning, culture, and language are three important concepts in anthropological linguistics (Foley, 1997). Meanwhile, in linguistic study, language has three important aspects, namely form, meaning, and function (Hameed, 2015). As a result, in this toponym research, the aspects of research include form, meaning, function, and cognition as one of the three forms of culture: ideas/cognitions, behaviors, and artifacts (Agustan, 2009).

The primary data of this research was the natural topographical toponyms of Siak Regency, complete with their meaning and origin. The research data were qualitative and secondary data. The data were obtained from the Bureau of Riau Provincial Secretariat Governance. In addition to the data, this research was also completed with the data in the form of texts that show the functions and systems of Siak Malay cognition regarding the natural topographical topography. The data were collected by using the library observation technique. After the data collection, the data were analyzed through reduction, identification, classification, interpretation, and synthesis. During the reduction phase, only 193 out of 209 toponyms in the Siak Regency were analyzed. This reduction is caused by the existence of toponyms that have no meaning and history.

Moreover, there was also data only in the form of meaning and/or the origin of naming, but they do not have a name/toponym. Next, the data were identified and classified according to the geographical aspects of their name and function. Finally, the data were interpreted and synthesized based on the tendency to toponym naming concerning the cognition system of supporting the community.

\section{RESUlt AND DiscuSSION}

\section{Forms and Functions of Toponyms in Siak Regency and Cognition System Reflected in it From River to Sultanate to Siak Regency}

Siak Regency is formed through Act Number 53 of 1999 and is one of 12 regencies/cities in Riau Province. From West to East, the landscape of the Siak Regency is an incline. The Western region is highland, while the East region is lowland. Hence, it is not surprising that many rivers are flowing from the West to the East. In addition to rivers, Siak Regency also has many lakes and capes. This condition is also caused by the swampy and wet type of soil. Siak Regency cannot separate from the Siak River and Siak Sri Indrapura Sultanate. Siak Regency is divide by the deepest river in Indonesia. This river is a traditional means of transportation in the eastern Sumatra to the Malay Peninsula. This river is also closely related to international trade in the region. This river and other rivers are also the means of transportation for Siak Sri Indrapura Kingdom mobility.

According to data from the Biro Tata Pemerintahan Sekretariat Daerah Provinsi Riau (2014) or Bureau of Riau Provincial Secretariat Governance, Siak Regency 


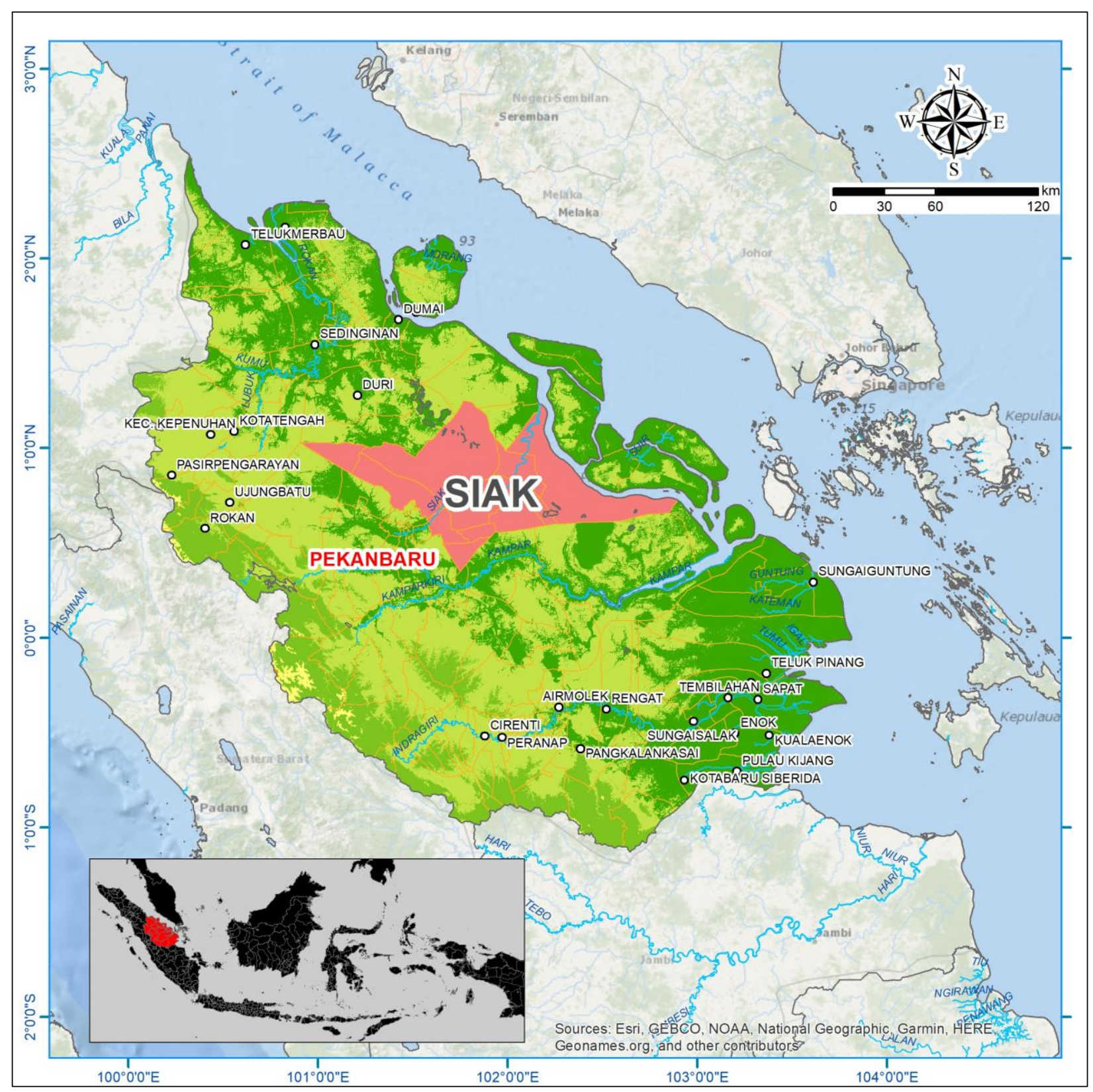

Figure 1. Siak Regency

(Source: ArcGIS Database (2019) modified by Author, 2019)

has 206 natural topographies in the form of hills (9), lakes (12), lakes (1), straits (1), capes (4), and rivers (179). Geographically, Siak Regency has a coastal area adjacent to several neighboring countries. The geoeconomic situation makes Siak Regency included in the growth triangle of Indonesia - Malaysia - Singapore.

Historically, Siak Regency cannot separate from Siak Sri Indrapura Kingdom. This kingdom was founded in 1723 AD by King Kecik titled Sultan Abdul Jalil Rahmat Syah. He is the son of the King of Johor, Sultan Mahmud Syah, with his wife, Encik Pong. The kingdom was centered on the edge of the Buantan River, the upstream of Siak River (the tributary of Siak River). However, due to various considerations, the kingdom center also had to move. It was moved from Buantan to Mempura, then to Senapelan Pekanbaru, returned to Mempura. Finally, the kingdom center moved to Siak Sri Indrapura during the reign of Sultan Ismail and Sultan Assyaidis Syarif Ismail Jalil Jalaluddin (1827-1864). During the reign of the $11^{\text {th }}$ Sultan, Sultan Assayaidis Syarief Hasyim Abdul Jalil Syaifuddin (1889-1908), a magnificent palace was built in Siak Sri Indrapura. Siak Palace has been designated as a Cultural Conservation since 2004 through a Ministerial Decree with registration number CB.442 (Ditjen Kebudayaan Kemdikbud, 2016).

Siak Sri Indrapura kingdom was known as an Islamic kingdom and had close relations with the Johor Kingdom in Malaysia. The last king of Siak kingdom, the $12^{\text {th }}$ Sultan, was Tengku Sulung Syarif Kasim titled Assayaidis Syarif Kasim Abdul Jalil Syaifuddin, also known as Sultan Syarif Kasim Tsani or Sultan Syarif Kasim II. When Indonesia achieved independence, he met Sukarno, the President of the Republic of Indonesia, and declared joining the Republic of Indonesia. At the 


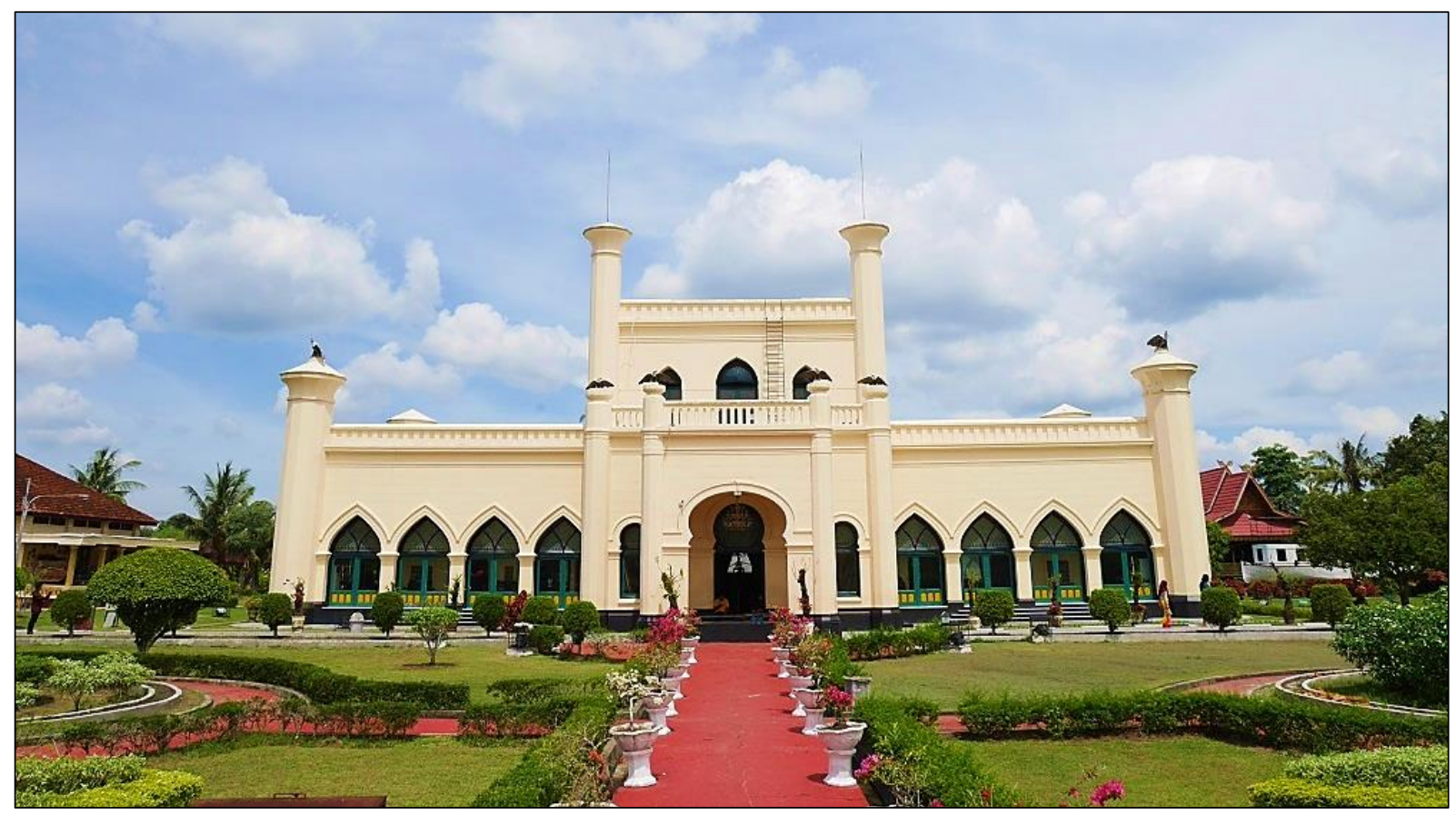

Figure 2. Siak Palace (Asseraiyah Hasyimia Palace)

(Source: Faridh, 2018)

same time, the Sultan also handed over the Royal Crown and ten thousand Guldens.

\section{Geographical, Social and/or Cultural Aspects of Natural topographical Toponyms in Siak Regency}

Natural topographical toponyms in Siak Regency include hills, lakes, lakes, straits, capes, and rivers. All of these topographies are present in the Riau Malay language. Each toponym consists of generic names and specific names. Generic names are the names of topographical elements such as mountains, hills, lakes, lakes, headlands, straits, and rivers. Specific names are the proper names that distinguish one topography from the others, including natural topographies in Siak Regency. The generic names of natural topographies in the Siak Regency are the same as the topographical names in Indonesian. Meanwhile, the proper names used are generally a lexicon of the Riau Malay language. Proper names have meanings that show their relationship with the geographical, social, or cultural aspects of the region that becomes the topographical location.

\section{Hill Toponym}

Hill's toponym in Siak Regency is closely related to its geographical and social aspects. There are eight data on hill toponym. Five hills are named after their geographical conditions, which are based on the physical-biological aspects of flora, fauna, and geomorphological physical aspects. Rimbasialangtombang Hill, Sialangmarakaluang Hill, Damarginak Hill are hill toponyms named after the names of flora and plants that are (widely) found in the hills. The name
Kencak Hill comes from the name of a lot of fauna or animals found in the hills, namely kencak (a type of squirrel). Sapitundang Hill is named after the geomorphological condition of the hill, in which the soil is striped or mottled (sapitundang). Bulunpanjang Hill, Lacuan Hill, and Bajarmelintang Hill are named after the social aspect of its environment. The toponyms of Bulunpanjang Hill and Bajarmelintang Hill are taken from the names of villages in the hilly region. Meanwhile, the toponyms of Lacuan Hill is taken from the word lancuan, which means 'a place for a cockfight.' There are cockfighting areas in the hill, based on these social events, the toponym Lacuan Hill is taken.

\section{Tasik (Lake) Toponym}

Lake Toponym is given based on geographical, social, and cultural aspects. Of the fourteen lake toponyms, twelve toponyms are named after their geographical aspects, namely from the biological, hydrological, geomorphological, and auditory aspects of flora and fauna. Besingin Lake, Betung Lake, Marbalu Lake, Metas Lake, Pepagar Lake, Sengko Lake, and Terung Asam Lake are named after the type of flora or plant, which are (widely) found in or around the lake. Burung Lake toponym is named after the lake condition, which is inhabited by many birds. Air Hitam Lake is named after the hydrological conditions of the lake; the water is black.

Meanwhile, Mungkal Lake and Bawah Lake are named after the geomorphological conditions of the lake. The word mungkal in Mungkal Lake toponym comes from the word tungkal or bertungkal, which means wavy in Bahasa Indonesia. The lake water is wavy, so the lake 


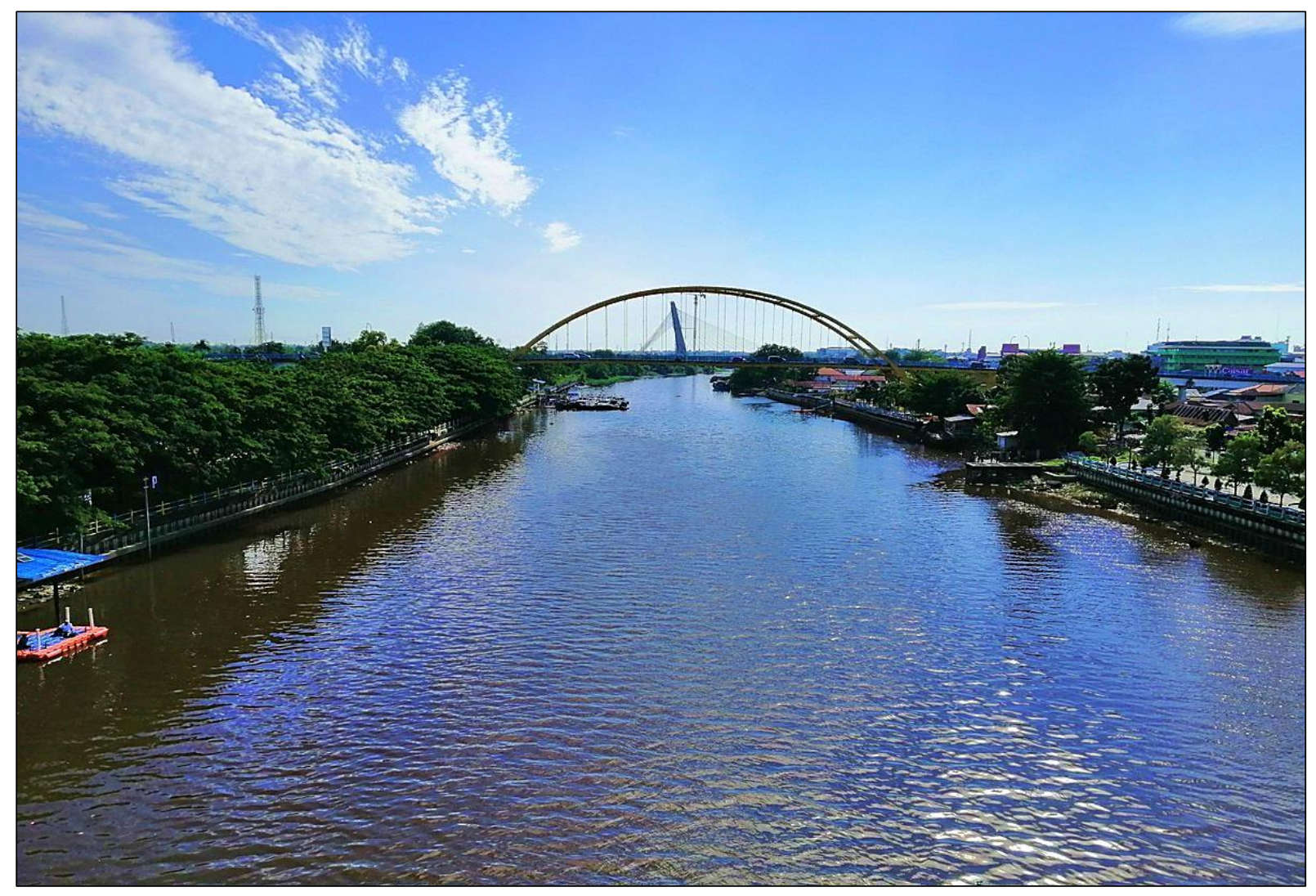

Figure 3. Siak River View

(Source: Sasmita, 2019)

is called Mungkal Lake 'lake which water is wavy'. The same as Mungkal Lake, Bawah Lake is named after the geomorphological condition of the lake. Bawah Lake is located under or below the ground level. Meanwhile, Ungus Lake toponym comes from the word ungus (Malay language), which means 'sound.' It is named that because the sound is often heard in the lake.

The two other lake toponyms, namely Belat Lake and Bunian Lake are named not based on the geographical aspect. Belat Lake is named after its social aspect. In the Riau Malay language, belat is the name of a tool for catching fish. There are many tools around the lake, so the lake is called Belat Lake. The other lake, namely Bunian Lake, is named after its cultural aspect. Bunian is a kind of spirit. The community believes that there are many spirits called bunian in the lake. Therefore, the lake is called Bunian Lake 'lake that has spirits, bunian.'

\section{Danau (Lake) Toponym}

In Siak Regency, there is a lake called Mul Lake. The naming of Mul Lake is social. Mul comes from the name of a company located near the lake, PT Mul. Thus, the lake near the company is called Mul Lake.

\section{Strait Toponym}

Strait is also found in Siak Regency. The natural topography is called Panjang Strait. The naming is geographical, especially geomorphological. The name Panjang Strait is related to the form of the strait, lengthwise. Therefore, the strait is called Panjang Strait.

\section{Cape Toponym}

Natural topography in the form of the cape is also found in Siak Regency, namely Jangkang Cape, Pedada Cape, and Buton Cape. The naming of Jangkang Cape and Pedada Cape are geographical, primarily biological, in the form of flora. Jangkang means 'the root part of the tree which protrudes above the ground' and pedada is the name of a plant/tree. Meanwhile, the naming of Buton Cape is social. Buton is 'board landfill.'

\section{River Toponym}

Natural topography in the form of the river is widely found in Siak Regency. The naming of these rivers is based on the geographical, social, and cultural aspects. The flora, geographical and biological aspects dominate the river topography. The vegetation or plants widely found in the river or surrounding area used as the name of the river. The followings are river toponyms.

$\checkmark$ Kangkatang River, kangkatang 'name of a plant,'

$\checkmark$ Kelakap River, kelakap 'name of a poisonous fruit tree,'

$\checkmark$ Kempas River, kempas 'name of a tree,'

$\checkmark$ Kepinis River, kepinis 'name of a tree,'

$\checkmark$ Ketapang River, ketapang 'name of a tree,'

$\checkmark$ Ketapang Besar River, ketapang 'name of a tree,'

$\checkmark$ Ketari River, ketari 'name of a tree,'

$\checkmark$ Kompasion River, kompasion 'name of a tree,'

$\checkmark$ Kunduk River, kunduk 'name of a fruit,'

$\checkmark$ Labutarap River, labutarap 'name of a tree,' 
$\checkmark$ Lalang River, lalang 'name of a grass,'

$\checkmark$ Lanjung Besar River, lanjung 'sugar cane tree,'

$\checkmark$ Lanjung Kanan River, lanjung 'sugar cane tree,'

$\checkmark$ Lekodiasam River, diasam 'sour fruit,'

$\checkmark$ Lekosindu River, sindu 'name of a tree,'

$\checkmark$ Lenggaung River, lenggaung 'jarung tree,'

$\checkmark$ Linau River, linau 'name of a tree,'

$\checkmark$ Lipai River, lipai 'name of a tree,'

$\checkmark$ Mendawai River, mendawai 'name of a rattan,'

$\checkmark$ Metas River, metas 'name of a tree,'

$\checkmark$ Minas River, minas, seminai 'tree/seminai wood' (clung by crude oil)

$\checkmark$ Minyak River, minyak 'name of a tree,'

$\checkmark$ Pauh River, pauh 'name of a tree,'

$\checkmark$ Pebaungan River, pebaungan 'name of a tree,'

$\checkmark$ Pelajau River, pelaju 'name of a tree,'

$\checkmark$ Penampo River, penampo 'scattered,'

$\checkmark$ Penampo Besar River, penampo 'scattered,'

$\checkmark$ Penampo Kecil River, penampo 'scattered,'

$\checkmark$ Pepagar River, pepagar 'name of a tree,'

$\checkmark$ Pinang River, Pinang 'name of areca tree,'

$\checkmark$ Pontianak Besar River, Pontianak 'name of a meranti tree,'

$\checkmark$ Pulai River, pulai 'name of a tree,'

$\checkmark$ Pulaigadang River, pulai 'name of a tree,'

$\checkmark$ Punok River, punok 'name of a tree,'

$\checkmark$ Rasaukuning River, rasaukuning 'name of a swamp plant,'

$\checkmark$ Raya River, raya 'big/flower name,'

$\checkmark$ Roboh River, roboh 'name of a tree,'

$\checkmark$ Sagu River, sagu 'name of a tree,'

$\checkmark$ Sengko River, sengko 'name of a tree,'

$\checkmark$ Siak River, siak 'name of a plant,'

$\checkmark$ Sialangpera River, sialangpera 'rubber tree infested by honee bee,'

$\checkmark$ Sikapas River, sikapas 'cotton tree,'

$\checkmark$ Simpangbakau River 'intersection and mangrove tree,'

$\checkmark$ Suakuban River 'a fern plant,'

$\checkmark$ Takelu River, takelu 'name of a fruit,'

$\checkmark$ Takuanabuluh River (takuana and 'buluh'),

$\checkmark$ Tasikbetung River, betung 'lake with lots of bamboo trees,'

$\checkmark$ Telang River, telang 'name of a bamboo,'

$\checkmark$ Tembutun River, tembutun 'name of a tree,'

$\checkmark$ Tonggak River, tonggak 'wood chips.'

River toponyms in Siak Regency also have geographical-biological fauna. The name of rivers taken from the name of the animals. Badar River, Keluang River, Keluang Kanan River, Lengkonaga River, Sarangbuaya River, Simpangpakam River, and Alurnaga River named after the name of the animals on the river or in the area around the river. Here is the meaning of river toponyms. $\checkmark$ Alurnaga River, naga 'big snake,'

$\checkmark$ Badar River, badar 'small-sized river fish,'

$\checkmark$ Keluang River, keluang 'big keluang,'

$\checkmark$ Lengkonaga River, naga 'dragon ring,'

$\checkmark$ Sarangbuaya River, 'crocodile nest/lots of crocodiles,'

$\checkmark$ Simpangpakam River, pakan 'caterpillar.'

In addition to being based on the geographical biological aspects, river toponyms in Siak Regency are also based on geographical, hydrological aspects of the river. Pendanau River, Libiba River, Sam-sam River, Airmenguruk River, Gelincir River, and Kili River 'downstream' are named after the river condition. Pendanau means 'shallow water or swamp.' Libiba means 'rumbling water due to clustered fish.' Meanwhile, Sam-sam River was named after the sour taste of the water. The name Airmenguruk River originates from the word airmenguruk 'disappearing water,' is a river that flows from upstream but disappears in downstream because it enters the ground and passes into an estuary. Gelincir River means 'rotten river.' The water stinks. Thus, it is called Gelincir River. The word kili in Kili River means 'to the downstream.' The river always flows downstream. Therefore, it is named Kili River, 'the river which water always flows downstream.'

River toponyms in Siak Regency are also geographical-geomorphological or based on the river topography. River toponyms illustrate the geomorphology of the river or the surrounding area.

$\checkmark$ Bukit River, bukit 'hill,'

$\checkmark$ Buku River, buku 'stack,'

$\checkmark$ Kuntung River, kuntung 'small hill around the river,'

$\checkmark$ Limau Besar River, limau 'five,'

$\checkmark$ Muarabungkal River, mungkal 'shallow estuary,'

$\checkmark$ Olak River, olak 'whirlpool,'

$\checkmark$ Pasir River, pasir 'sand,'

$\checkmark$ Pematangrobah River, pematangroba 'fallen embankment,'

$\checkmark$ Perawang River, rawang 'swamp,'

$\checkmark$ Rawa River, rawa 'swamp,'

$\checkmark$ Tasikmangulu River, mangulu 'shallow swamp,'

$\checkmark$ Tasiksemilan River, semilan 'nine

$\checkmark$ Sendebu River, sendebu 'hole,'

$\checkmark$ Simpangtasik River, 'lake intersection.'

Bukit River is named after the river geomorphology, in which there are many small hills on the riverbanks. The name Buku River originates from the existence of mounds of earth in the middle of the river, which has never been eroded by the river currents. Kuntung River named after its meaning, 'small hills around the river.' Limaubesar River toponym comes from the word limau, which means 'five.' The meaning refers to the number of the river (five), which leads to Siak River located in 
Limau River Village, Pusako District. The name Muarabungkal River comes from the word bungkal, which means 'shallow.'

It is because geomorphologically, the river is a shallow estuary, so it is called the Muarabungkal River. Olak means 'whirlpool'. Because it is olak in the river, it is named Olak River. Pasir River was named after its geomorphological condition. There is much sand in the river starting from upstream to downstream during the rainy season. Pematangroba River 'fallen embankment' is named so because there are fallen embankments around the river. The naming of Perawang River is also the same as the naming of Pematangroba River, which is based on the geomorphological conditions around the river. There are many swamps around Perawang River, so the river is called Perawang River (rawang 'swamp'). Likewise, it is in line with the naming of Rawa River and Tasikmangulun River. The difference is that Tasikmangulun River has shallow swamps. In the Riau Malay language, mangulun means 'shallow swamp. '

Meanwhile, Tasiksemilan River named after the number of lakes located around the river, which is nine. In Sendebu River there are many holes 'sendebu'. Accordingly, the river called Sendebu River 'river, which has holes'. The name Simpangtasik River originates from the river location, which is at the lake intersection.

In Siak Regency, there is one river named after a combination of the geographical aspects: place names and fauna names, namely Minaspelampung River. Minas is the name of a place passed (geographically) while pelampung is a type of fish, lampung fish.

River toponyms in Siak Regency also have auditory characteristics. Mandiangin River and Tasikungusi River named after events of strong winds 'mandiangin' and sounds 'ungus' around the river.

\section{Social Aspect}

There are also river toponyms in Siak Regency named after the social aspect, such as village names crossed by the river, name of equipment used by the community, past activities or events, people names, tribal names, traits, and cape names.

Gasip River, Belutu River, Muara Kelantan River, Limbungan River, Limbungan River, Gelanggang River, Cabang Mempura River, Lakar River, Bemual River, and Kimas River named after the villages become the location of the rivers.

Lukut, gadang, tamba, bungkai, anakbelat, and bumbung are tools that names used as river toponyms. Lukut is a bird trapping tool. In Lukut River, there are many people who trap birds, so it is called Lukut River. Gadang River toponyms come from the word gadang, which means 'tambour.' The name was given because a tambour is used by the lost indigenous people to find their friends in the forest around the river. The name
Tamba River comes from the word tambak, which means 'road.' In the area, the river is the only means of transportation in the past, so it is called the Tamba River, which means a river which is used as a road. The name Bungkai River comes from the word bungkai, which means 'rice package.' People who live around the river carry bungkai as a prepared meal when going to the forest.

Meanwhile, the name Anakbelat River comes from the word belat, which means 'fishing gear.' It is named so since there are many belat installed by the community there. The name Bumbung River comes from the word bumbung, which means 'wood perforated to catch fist.' Bumbung is installed in the river so that the community uses it as a marker or the name for the river.

In terms of social, river toponyms in Siak Regency were named after certain activities related to the river. On Tapih River, the ancient community carries out activities of washing, cleaning, or filtering (tapih means' filter'). The name of the Bongkor River originates from past activities that occur in the river, namely bongkor 'unload,' more precisely loading and unloading goods. The name of Leko River comes from past activities or events that take place on the river as a meeting place. The people in the area call it leko, which means 'glancing.' The name of Lekodiatap River comes from past activities on the river; that is, people make huts on the riverbanks.

Meanwhile, the name Bekalar River originates from the word bekalar, which means 'scratching while joking.' The name Sengketo River (sengketo 'dispute') is related to the community condition around the river, which does not get along or is in dispute. Polong River (polong 'helping') is also named after people's attitudes around the river, which is helpful. The name Seliau River comes from the word si, which means 'died.' In ancient times, many people died around the river because of a lack of healthcare. Chinese who arrived there name it Seliau River.

Figure's names also become the source of rivers naming in the Siak Regency. Libo River, Libocabang River, Sutanlelo River, Acong River, Tasip River, Tapiantukpatih River, and Lanus River are named after characters. Libo is the name of a tribal child born on the bank of Libo River. Sutanlelo is the name of a rattan carrier who likes to cross the rivers. Acong is a Chinese who lives in the riverbank. Tasip or Tuk She is a Chinese merchant who lives in the river environment. Tukpatih is a magical figure who lives near the river, so the river is named Tapiantukpatih River. In addition to good figures, the riverbank in Siak Regency is also inhabited by evil characters, namely lanun/lanus. The river where they gather is called Lanus River.

There are also rivers which named for the subjective reasons of the community - for example, Kelembaya River, Rutuh River, Berkelnaning River, Mempandang 
River, Umu River. People consider the Kelembaya River a dangerous river. Hence, the river is called 'dangerous Kelembaya River.' The name of Rutuh River comes from a word that means 'intact or durable.' The river cannot use as land for fishing, so the fish there is considered intact. Thus, the community names it Rutuh River. Tanggananing River means 'the river is always dizzy.' The community gave the name because the river flow confuses fishers. The name Mempandang River originates from the word mempandang, which means 'people who do not care.' The river is named so because people who live around the river do not like to help each other. The Umu River means 'Old River.' People appreciate that the river has been around for a long time.

\section{Cultural Aspect}

Legends and myths are the sources of rivers naming by the people in the Siak Regency. Tasikbunian Kecil River, Lancang River, Lancang Kecil River, Benayah River, and Dulang River, and Patahkail River come from legends. The Tasikbunian River is named after the myth related to the river, which is inhabited by spirits (people who live in it). Lancang River and Lancang Kecil River are named after the legend that the rivers used to wash away lancing (small boats are containing offerings). Benayah River is named after a legend about a child who states the truth truthfully.

Meanwhile, the name Dulang River comes from the word dulang, a royal tray that is often found in the river. The name Patahkail River comes from the story of a broken hook of a lady from the land of Siak fishing on the river. Therefore, the river is called Patahkail River.

River toponyms are numerous and the greatest in number among natural toponyms in Siak Regency. The toponym is underlain by a variety of geographical aspects: physical, social, and cultural aspects. The physical geographical aspect includes biological (flora and fauna), hydrological, geomorphological, tools, tastes, sounds, smells, conditions, and oil. The social aspect includes specific places, past activities, people names, tribal names, tools, objects, village names that crossed, subjective reasons of the community. There is only one cultural aspect, namely, legend. Meanwhile, there is a combination of physical and social aspects, namely a specific place that is combined with a fish name. The most prominent aspect is the physical geographical aspect, while the least prominent aspect is the cultural aspect.

There is a similarity between the results of this research with the research results by Ruspendi and Mulyadi (2014). The similarity is the relation between aspects underlying the toponym. Toponyms in Siak Regency and Cirebon Regency are both underlain by physical, social, and cultural geographical aspects. The physical aspect that stands out is also the same, namely flora (vegetation or plants). Based on the aspect of naming considerations as conveyed by Mutakin (1999), toponyms in Siak Regency only consider the aspect of the experience that is related to the natural processes and human engineering. From the data, it can see that there is no toponym given because of consideration of ideas, hopes, ideals, and personal tastes towards a place or characteristics/traits that have been given by nature itself (given).

\section{Toponym Functions}

Natural topographical toponyms in the form of hills, lakes, lakes, capes, straits, and rivers in the Siak Regency serve to mark, become an identity, describe, and remind a historical background and/or socio-cultural background of a landscape. Marking or labeling a landscape or topography is among the toponym functions in Siak Regency. The label or mark serves as a crossreference between concepts and references in communication. The referential nature brings reality in communication events. When referring to Kelembaya River toponym, for example, people will remember or point the river mentioned by the name. Kelembaya River is a mark for a landscape in the form of a river.

The toponym in Siak Regency also functions as an identity. Within that limitation, the toponym of a landscape is different from other landscapes. Thus, Mandau River is different from Layang River; Bungkai River is not the same as Belati River, for example. The function as identity is also the same as the toponym function in Latvia in the Cekula's (2016) research. Furthermore, the toponym in Siak Regency also describes the characteristics of a landscape. These typical characteristics can be in the form of characteristics of the physical, social, and cultural aspects and a combination of social and physical aspects. Pinang River, for example, provides information about the river where there are many areca trees. Samsam River is a river with acidic water. Pematangrobah River provides a depiction or description of a river that is marked by the existence of the fallen embankment around it. Toponym in Siak Regency also serves to remind of historical, social, and cultural events related to particular landscapes. Polong River reminds people of the community living around the river to help or work together. Lancang River reminds people of a river that is used as a place to anchor a ship containing offerings.

\section{Cognition System of Siak Malays Reflected in Natural Topographical Toponyms in Siak Regency}

The linguistic elements used for natural topographical toponyms in Siak Regency show the strong environmental influences in the cognition system of Siak Malays in naming the natural topographical 
elements. In the cognition system of the Siak Malays, their natural environment is an ecosystem consisting of physical, social, and cultural (geographical) aspects. The physical aspect of natural topographies dominated by flora, fauna, hydrology, and geomorphology. The social environment of natural topographies consists of places, past activities, figures, tribes, ceremonial instruments, objects, villages, and subjective reasons. The cultural environment of topographies can be in the form of legends and myths.

In the cognition system of Siak Malays, there is a process of utilizing and connecting between environmental aspects and natural topographies. The names they give to the landscapes are names that exist in their environment. Moreover, the linking process also occurs with prior knowledge. The names of physical, social, or cultural environmental aspects that already exist (as prior knowledge) are associated with the natural topographical toponyms that they will name.

There are two concepts in the cognition system of Siak Malays, namely assimilation and accommodation. Assimilation took place when Siak Malays absorbed new information into information already in their cognitive systems. The new information is a natural toponym, while the old information is the name of physical, social, and cultural aspects in the environment. Meanwhile, the concept of accommodation occurs when Siak Malays use existing information or knowledge to solve their problems. The information or knowledge that already exists is the names of the physical, social, and cultural aspects that already exist in the environment of the Siak Malays. On the other hand, the problem faced is the naming of natural topographical elements.

In terms of knowledge concept, the cognition system of Siak Malays is strongly influenced or dominated by empirical concepts rather than social or cultural concepts. Siak Malays generally use names derived from the physical environment rather than the social or cultural environment. Natural topographical toponyms are based on the dominant physical environment in the natural topography. Toponyms can be derived from the names of flora, fauna, geomorphology, hydrology, and others that are widely found in the natural topographies.

The interest of Siak Malays in the physical aspect than others shows that the Siak Malays prioritize essential things, something that the senses can recognize rather than abstract things that the senses cannot recognize. This rationality is very acceptable as a reference for the natural topographies. When referring to topography, Siak Malays are sufficient to see the existing physical aspect around the topography. The simplicity of rationality is very appropriate when toponyms are given.

From the behavior pattern of giving toponyms in the natural topographies by Siak Malays, creativity elements can be found in the cognition system of Siak Malays.
Creativity is to name their natural topographies with the name of the existing environmental aspect. They only use distinguishing generic elements between the names of various elements of toponyms sources and natural topographical toponyms. For example, the names bunut tree, kangkatang tree, and kempas tree use as the river toponyms into Bunut River, Kangkatang River, and Kempas River. The village names, for example, Rantaupanjang Village, Buantan Village, and Mengkap Village are used as the river toponyms for Rantau Panjang River, Buantan River, and Mengkap River.

\section{Conclusion}

The discussion of natural topographical toponyms in the Siak Regency leads to four general conclusions. First, natural topographical toponyms in Siak Regency have specificity, which is very carefully related to the topographical environment. Typical physical, social, or cultural aspects in the environment of topography used as the source of the topographical name. For example, it comes from the names of flora, fauna, geomorphology, village, characters, tribes, and legends.

Second, toponyms in Siak Regency are the same as toponyms in various parts of the world, which have functions. These functions are always related to humans as creators. Toponyms in Siak Regency serve to mark, become an identity, describe, and remind a historical background and/or social culture of natural topography.

Third, from the toponyms pinned on various natural topographies in Siak Regency, it can be seen that the cognition system of Siak Malays is related to the natural topography. It is strongly influenced by the environment, especially the physical environment rather than the social and cultural environments. It also undergoes a process of utilizing and connecting with the existing knowledge in their cognition. Besides, it also contains the concepts of assimilation, accommodation, and creativity. Related to the natural topographical toponyms, it is very empirical compared to the social and cultural aspects.

Fourth, toponyms in Siak Regency are not underlain by certain expectations, ideals. Besides, there are no toponyms with specific building backgrounds found.

In addition to the four conclusions above, this research also has several implications. First, is there still a typical phenomenon that becomes the name of a particular natural topography nowadays? For example, is there still flora, fauna, geomorphological conditions, certain conditions that become the origin of the names in the topographical location? If not, specific actions should be carried out in order to maintain the natural balance.

Second, topographical toponyms research in Siak Regency can contribute to people's understanding of the physical, social, and cultural environments of the traditional communities that names topography. 
Third, toponyms research also provides geosphere information about minerals contained in the natural topographies in Siak Regency because of the existence of topographies with physical characteristics that indicate certain mineral content. For example, there is a river that is acidic, black and stinks, and there are materials contained in the topographies.

\section{ACKNOWLEDGEMENT}

The author would like to thank the Bureau of Riau Provincial Secretariat Governance for providing data for this research. Special thanks to Mr. Agus and Mr. Abi for providing time to find and copy the data needed.

$* * * * *$

\section{REFERENCES}

Agustan. (2009). Toponim daerah Jawa Barat (3). Retrieved February 8, 2018, from Peta dan Toponimi website: https://agustan.wordpress.com/2009/01/12/toponimidaerah-jawa-barat-3/

ArcGIS Database. (2019). GEBCO 2019 Basemap (NOAA NCEI Visualization). Retrieved April 2, 2020, from ArcGIS Hub website: http://hub.arcgis.com/datasets/

Assadorian, A. (2017). On the Toponymy of the Iranian Azerbaijan. Advances in Anthropology, 7(3), 146-153.

Biro Tata Pemerintahan Sekretariat Daerah Provinsi Riau. (2014). Asal-usul toponimi rupabumi alami Provinsi Riau. Pekanbaru: Pemerintah Provinsi Riau.

Cekula, Z. (2016). Place names and identity: place names of Northern and Southern Latgale reflecting vegetation. In C. Hough \& D. Izdebska (Eds.), Proceedings of the 25th International Congress of Onomastic Sciences Vol. 1. Glasgow: University of Glasgow.

Ditjen Kebudayaan Kemdikbud. (2016). Istana Siak Sri Indrapura. Retrieved March 14, 2019, from Sistem Registrasi Nasional Cagar Budaya website: http://cagarbudaya.kemdikbud.go.id/cagarbudaya/detail /PO2016022200062/istana-siak-sri-indrapura

Faridh, I. (2018). Megahnya Istana Siak dan Taman Nasional Zamrud di Riau. Retrieved June 7, 2019, from Irham Faridh Journey Diaries website: http://www.irhamfaridh.com/2018/01/megahnya-istana-siak-dan-tamannasional.html

Foley, W. A. (1997). Anthropological Linguistics: An introduction. Oxford: Blackwell Publishers Ltd.

Hameed, A. (2015). (2015). Language: form, meanings and fuctions. Retrieved February 12, 2019, from Semantics (2) website: https://fdocuments.net/document/semantics-2-dr-ansa-hameed-previously-semantics-study-ofmeanings.html

Helleland, B. (2012). Place Names and Identities. Oslo Studies in Language (OSLa), 4(2), 95-116.

Jordan, P. (2014). Place Names as an Expression of Human Relations to Space. In C. Hough \& D. Izdebska (Eds.), ICOS (pp. 209-223).
Kleinedler, S. (2014). Webster's New World College Dictionary, Fifth Edition. Massachusetts: Houghton Mifflin Harcourt Publishing Company.

Klugah, M. A. (2013). Recounting history through linguistics: A toponymic analysis of Asogli migration narratives. African Journal of History and Culture, 5(8), 151-159.

Kramsch, C., \& Widdowson, H. G. (1998). Language and Culture. Oxford: Oxford University Press.

Madden, D. J. (2018). Pushed Off the Map: toponymy and the politics of place in New York City. Urban Studies, 55(8), 1599-1614.

Moleong, L. J. (2014). Metode Penelitian Kualitatif. Bandung: Remaja Rosdakarya.

Mutakin, A. (1999). Pengantar Ilmu Sosial. Bandung: PT Grasindo.

Nazir, M. (2003). Metode Penelitian Cetakan Kelima. Jakarta: Ghalia Indonesia.

Permendagri. Pedoman Umum Pembakuan Nama Rupabumi., Pub. L. No. 39 (2008). Indonesia.

Perpres. Tim Pembakuan Nama Rupabumi. , Pub. L. No. 112 (2006). Indonesia.

Qian, S., Kang, M., \& Weng, M. (2016). Toponym mapping: a case for distribution of ethnic groups and landscape features in Guangdong, China. Journal of Maps, 12(1), 546-550.

Rais, J., Lauder, M. R. M. T., Sudjiman, P., Ayatrohaedi, Sulistiyo, B., Wiryaningsih, A., ... Santoso, W. E. (2008). Toponimi Indonesia: sejarah budaya yang panjang dari pemukiman manusia dan tertib administrasi. Jakarta: Pradnya Paramita.

Ruspandi, J., \& Mulyadi, A. (2014). Fenomena Geografis di Balik Makna Toponimi di Kota Cirebon. Jurnal Geografi Gea, 14(2), 1-13.

Sasmita, L. W. (2019). Jembatan Sungai Siak Pekanbaru. Retrieved June 17, 2019, from Lina W. Sasmita Adventure-Traveling-Hiking-Island Hopping website: https://www.linasasmita.com/2019/02/jembatansungai-siak-pekanbaru.html

Sugiyono, P. (2013). Metode Penelitian Pendidikan Pendekatan Kuantitatif, Kualitatif, dan R\&D. Bandung: Alfabeta.

Tent, J. (2015). Approaches to Research in Toponymy. Names, 63(2), 65-74.

Tent, J., \& Blair, D. (2011). Motivations for Naming: The Development of a Toponymic Typology for Australian Placenames. Names, 59(2), 67-89.

Thornton, T. F. (1997). Anthropological Studies of Native American Place Naming. American Indian Quarterly, 21(2), 209.

Tim Redaksi KBBI. (2018). Kamus Besar Bahasa Indonesia (5th ed.). Jakarta: Badan Pengembangan dan Pembinaan Bahasa Kementerian Pendidikan dan Kebudayaan.

Tyler, S. A. (1969). Introduction. In Cognitive Anthropology: readings. New York: Holt, Rinehart, and Winston.

Wierzbicka, A. (1997). Understanding cultures through their key words: English, Russian, Polish, German, and Japanese Vol. 8. Oxford: Oxford University Press on Demand. 